\title{
Structural characterization of stalk lignin from banana plant
}

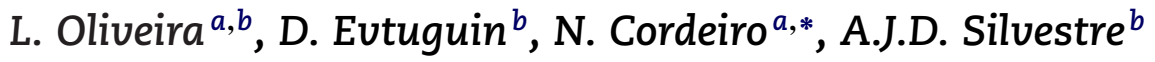 \\ a CEM and Department of Chemistry, University of Madeira, 9000-390 Funchal, Portugal \\ b CICECO and Department of Chemistry, University of Aveiro, 3810-193 Aveiro, Portugal
}

\section{A R T I C L E I N F O}

\section{Article history:}

Received 15 January 2008

Received in revised form

6 April 2008

Accepted 11 April 2008

\section{Keywords:}

Lignin

Musa acuminata Colla var. Cavendish

Rachis

Floral stalk

Banana plant

${ }^{13} \mathrm{C}$ NMR

${ }^{1} \mathrm{H}$ NMR

\begin{abstract}
A B S T R A C T
Dioxane lignins from two fractions of banana plant 'Dwarf Cavendish' stalk (floral stalk $\left(\mathrm{DL}_{\mathrm{FS}}\right)$ and rachis $\left(\mathrm{DL}_{\mathrm{R}}\right)$ ) were structurally characterized by a set of spectroscopic (Ultraviolet (UV), FTIR, solid- and liquid-state NMR) and chemical degradation (permanganate (PO) and nitrobenzene oxidation (NO)) techniques. Despite both lignins are of HGS-type, strong structural differences were observed between them. Thus, $\mathrm{DL}_{\mathrm{FS}}$ showed almost twice the abundance of $\mathrm{H}$ and $\mathrm{G}$ units and almost half of the abundance of $\mathrm{S}$ units when compared to $\mathrm{DL}_{\mathrm{R}}$. $\mathrm{DL}_{\mathrm{R}}$ possessed significantly higher amount of $\beta-0-4^{\prime}$ structures $\left(0.32 / \mathrm{C}_{6}\right.$ against $\left.0.12 / \mathrm{C}_{6}\right)$ and the molecular weight $\left(5400 \mathrm{Da}\right.$ against $3750 \mathrm{Da}$ ) than those of $\mathrm{DL}_{\mathrm{FS}}$. About $72 \%$ of the condensed structures in $\mathrm{DL}_{\mathrm{FS}}$ are of $\beta-5$ and $5-5^{\prime}$ types, whereas 4-0-5'-diaryl ether structures were the most abundant condensed structures in $\mathrm{DL}_{\mathrm{R}}$. Most of $\mathrm{H}$ units in both lignins are terminal phenolic coumarates linked to lignin substructures by ester bonds. Both lignins are structurally associated with suberin-like components in cell wall tissues. Structural features of stalk lignin were discussed in terms of possible restrictions for the kraft pulping of integral stem material.
\end{abstract}

(C) 2008 Elsevier B.V. All rights reserved.

\section{Introduction}

In the last years, a significant attention has been paid to the new sources of vegetable fibres, alternative to wood raw materials, for the pulp and paper applications and biocomposites. Banana plant, a monocotyledonous annual herbaceous plant, has been suggested as a suitable crop for these types of applications (Cordeiro et al., 2004, 2005; Faria et al., 2006).

Annually about 72.5 million tons of bananas are produced (FAO, 2006), being the Cavendish variety the most produced and exported, corresponding to about $1 / 3$ of the world production. After harvesting of the single bunch of bananas, a considerable amount of agricultural residues are produced, where the foliage, pseudo-stem and rachis are the most important morphological parts in terms of produced volume and of fibre quality. Since the above plant materials are available in the banana producing regions during all the year, these can be an important industrial source of fibres and chemicals, thus constituting an additional economical profit to farmers (Reddy and Yang, 2005).

One of the macromolecular components that plays an important physiological role in plant and determine the chemical processing of cellulosic fibres is lignin (Terashima and Fukushima, 1993). Regarding the pulp and paper applications, the amount and the structure of lignin determine the pulping and bleaching responses of the plant material. The lower the lignin content and the proportion of condensed structures in lignin, the less energy and reagents consumption are normally needed for the chemical pulping and bleaching processes. In contrast, the presence of high lignin concentrations in the middle lamella of plant cells is advantageous, for example, for the fibreboard production. The lignin has excellent compatibility with the thermosetting resins commonly used in

\footnotetext{
* Corresponding author. Tel.: +351 291705 107; fax: +351 291705149.

E-mail address: ncordeiro@uma.pt (N. Cordeiro). 
fibreboard manufacture and contributes itself as an adhesive between fibres (Donaldson et al., 2001).

As part of a global research project, aiming to find new applications for 'Dwarf Cavendish' (Musa acuminata Colla var. cavendish) vegetal residues, we have studied the chemical composition of the plant tissues from different morphological regions of this banana plant variety (Oliveira et al., 2005, 2006a,b, 2007). These studies revealed the significant variations in the chemical composition and the structure of components from different morphological parts. Thus, a cellulose content of $37.3 \%$ in leaf sheaths and only $15.7 \%$ in floral stalk was found; the starch content varied between $26.3 \%$ in floral stalk and $0.4 \%$ in petioles/midrib; the lignin content varied between $24.3 \%$ in leaf blades and $10.5 \%$ in rachis and the amount of lipophilic extractives was $5.8 \%$ in leaf blades and $1.2 \%$ in petioles/midrib. These findings allowed some propositions on the eventual utilization of different parts of banana plant and to formulate some restrictions for their integral processing. In particular, the successful kraft pulping of pseudo-stem was explained by a relatively low content (about 13\%) and particular structure of lignin in leaf sheaths (high proportion of S units and low condensation degree) of the banana plant (Oliveira et al., 2007). At the same time, the preliminary results on the lignin structure in stalk, another counterpart of pseudo-stem, indicated its eventual negative effect on the total pulping efficiency and pulp quality, indicating that these two parts of pseudo-stem (leaf sheaths and stalk) should be separated before pulping (Oliveira et al., 2007). In this context, additional information on stalk lignin structure would be helpful to evaluate the risks of the integral stem pulping.

In the present work, lignins from the internal (floral stalk) and external (rachis) stalk parts of 'Dwarf Cavendish' were characterized by a set of wet chemistry and spectroscopic (Ultraviolet (UV), FTIR and NMR) methods aiming to provide new structural information on these lignins and to justify the pseudo-stem fractionation before the pulping applications.

\section{Materials and methods}

\subsection{Preparation of plant material}

Floral stalk and rachis from mature banana plants 'Dwarf Cavendish' were collected in Madeira Island (Portugal) (Oliveira et al., 2007). The air-dried materials were milled in a Retsch AS200 and sieved to 40-60 mesh fractions. This fraction was submitted to successive extractions with ethanol/toluene $(2: 1, \mathrm{v} / \mathrm{v})$ for $4 \mathrm{~h}$ followed by water for $6 \mathrm{~h}$. The extractives contents were $3.2 \%$ and $9.6 \%$ (o.d. material) in floral stalk and $3.4 \%$ and $14.7 \%$ (o.d. material) in rachis, respectively (Oliveira et al., 2007).

\subsection{Isolation of lignins}

Lignins from floral stalk and rachis were isolated by acidolysis from alkali pre-extracted sawdust in a nitrogen atmosphere by the dioxane method as described previously (Oliveira et al., 2006a). Briefly, the sample was submitted to treatment with $0.3 \% \mathrm{NaOH}$ solution during $1 \mathrm{~h}$ under reflux, exhaustively washed with distilled water and dried. Then, the alkali pre-extracted sawdust was submitted to three sequential extractions (30 min each) with a dioxane-water (9:1, v/v) solution containing $0.2 \mathrm{M} \mathrm{HCl}$ under reflux in a nitrogen atmosphere. After the dioxane-water wash, each portion of extract was concentrated separately, the resulting fractions were combined, and lignin was precipitated in cold water. The lignin was centrifuged, washed with water until pH 6 and freezedried. The lignin yields were about $37 \%$ and $33 \%$, based on the Klason lignin in the alkali pre-extracted plant, for floral stalk and rachis, respectively.

Dioxane lignins were purified by two sequential purification steps: an extraction step with dioxane:methanol followed by an exhaustive chloroform extraction. These purified lignins (designated $\mathrm{DL}_{\mathrm{FS}}$ and $\mathrm{DL}_{\mathrm{R}}$, for floral stalk and rachis lignin, respectively) were submitted to structural characterization analysis, representing about $22 \%$ and $20 \%$ of lignin in the alkali pre-extracted plant (based on Klason lignin) for floral stalk and rachis, respectively.

\subsection{Chemical analysis}

The alkaline nitrobenzene oxidation (NO) as well as the permanganate oxidations (PO) of in situ and isolated lignins were performed as described previously (Gellerstedt, 1992; Chen, 1992). The analysis of methoxyl groups was performed by Zeisel method (Zakis, 1994). The residual neutral sugars in the lignin sample were analyzed by GC as described previously (Blakeney et al., 1983). The elemental composition was determined on a LECO CHNS-932 instrument.

\subsection{Size exclusion chromatography}

Lignins $(0.5 \%, \mathrm{w} / \mathrm{w})$ were dissolved in $0.1 \mathrm{M} \mathrm{LiCl}$ dimethylformamide (DMF) and analyzed by Size Exclusion Chromatography (SEC) using a PL-GPC 110 chromatograph equipped with a pre-column Plgel $5 \mu \mathrm{m}$ and two Plgel $5 \mu \mathrm{m}$ Mixed D $300 \mathrm{~mm} \times 7.5 \mathrm{~mm}$ columns at $70^{\circ} \mathrm{C}$. A solution of $0.1 \mathrm{M} \mathrm{LiCl}$ in DMF, used as an eluent, was pumped at a flow rate of $0.9 \mathrm{~mL} / \mathrm{min}$. The SEC columns were calibrated using lignin preparations previously characterized by ESI/MS (Evtuguin et al., 2001).

\subsection{UV, FTIR and ${ }^{13} \mathrm{C}$ CP-MAS NMR}

Ultraviolet (UV) spectra were recorded in 2-methoxyethanol solutions on a JASCO V-560 UV/vis spectrophotometer using $1 \mathrm{~cm}$ thick cell. Infrared (FTIR) spectra were recorded on a Mattson 7000 FTIR spectrometer in $\mathrm{KBr}$ pellets $(1 / 250 \mathrm{mg})$. The spectra resolution was $4 \mathrm{~cm}^{-1}$ and 132 scans were averaged. ${ }^{13} \mathrm{C}$ solid-state NMR spectra were recorded at $100.6 \mathrm{MHz}(9.4 \mathrm{~T})$ on a Bruker Avance 400 spectrometer, with a 7-mm double bearing Bruker rotor, spun in air at $5.0 \mathrm{kHz}$. The Cross Polarization-Magic Angle Spinning (CP-MAS) spectra were recorded with a $5 \mathrm{~s}$ recycle delay and a $2 \mathrm{~ms}$ contact time. About 10,000 scans were collected. In all experiments the ${ }^{1} \mathrm{H}$ and ${ }^{13} \mathrm{C} 90^{\circ}$ pulses were ca. $4 \mu \mathrm{s}$. 


\subsection{Liquid-state NMR}

The NMR spectra were recorded on a Bruker Avance 300 spectrometer using TMS as an internal reference. The ${ }^{1} \mathrm{H}$ NMR spectra of acetylated lignin was obtained using $\mathrm{CDCl}_{3}$ solution ( $2 \%$ concentration), at $300 \mathrm{MHz}$ and room temperature, with a $3 \mathrm{~s}$ delay, $12.2 \mu \mathrm{s}$ pulse width $\left(90^{\circ}\right)$ and 300 scans. The ${ }^{13} \mathrm{C}$ NMR spectra were recorded at $75.5 \mathrm{MHz}$ and $318 \mathrm{~K}$ using 5 -mm-diameter tubes. The concentration of lignin samples in $\mathrm{DMSO}-\mathrm{d}_{6}$ was ca. $23 \%(\mathrm{w} / \mathrm{v})$. In the case of floral stalk lignin a previous acetylation was needed. The inverse gated decoupling sequence, which allows quantitative analysis and comparison of signal intensities, was used with the following parameters: $90^{\circ}$ pulse angle; $12 \mathrm{~s}$ relaxation delay; $16 \mathrm{~K}$ data points and 18,000 scans. HSQC spectra were acquired using the follow parameters: temperature $313 \mathrm{~K}$; a $90^{\circ}$ pulse width of $10 \mu \mathrm{s}, 1.5 \mathrm{~s}$ pulse delay $\left(d_{1}\right)$, and ${ }^{1} \mathrm{~J}_{\mathrm{C}-\mathrm{H}}$ was optimized for $146 \mathrm{~Hz}$.

\section{Results and discussion}

The dioxane lignins were isolated from floral stalk (DLFS) and rachis $\left(D L_{R}\right)$ according to a previously developed procedure (Oliveira et al., 2006a) and structurally characterized. Similarly to leaf sheaths lignin (Oliveira et al., 2006a), the yields of DLFS and $\mathrm{DL}_{\mathrm{R}}$, based on Klason lignin in the alkali pre-extracted plant, 37\% and 33\%, respectively, were lower when compared to the yields obtained for other annual plants, such as reed and kenaf (Seca et al., 1998, 2000). This can be explained by a strong structural association of in situ 'Dwarf Cavendish' lignin with polysaccharides and especially, with lipophilic compounds.

The elemental composition of $\mathrm{DL}_{\mathrm{FS}}$ and $\mathrm{DL}_{\mathrm{R}}$ was as follow: C, 56.7\% and 55.0\%; O, 37.9\% and 39.4\%; $\mathrm{H}, 5.4 \%$ and $5.6 \%$, respectively. Lignins contained a small amount of residual polysaccharides $(<1 \%)$ and ashes $(<3 \%)$. The empirical formulas on C9 were calculated based on analyses of methoxyl groups and elemental composition (with correction to the ash content): $\mathrm{C}_{9} \mathrm{H}_{9.37} \mathrm{O}_{4.25}\left(\mathrm{OCH}_{3}\right)_{0.54}(\mathrm{Mr}=202.1)$ for $\mathrm{DL}_{\mathrm{FS}}$ and $\mathrm{C}_{9} \mathrm{H}_{8.92} \mathrm{O}_{4.28}\left(\mathrm{OCH}_{3}\right)_{1.20}(\mathrm{Mr}=222.0)$ for $\mathrm{DL}_{\mathrm{R}}$. The notable discrepancy in the methoxyl content clearly indicated the significant structural difference between these two lignins, which were studied in more details.

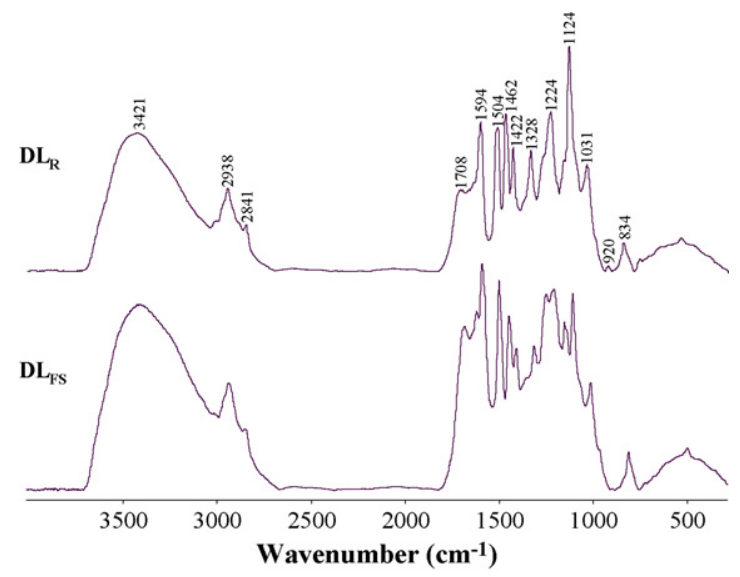

Fig. 1 - FTIR spectra of floral stalk (DLFS) and rachis lignins $\left(\mathrm{DL}_{\mathrm{R}}\right)$.

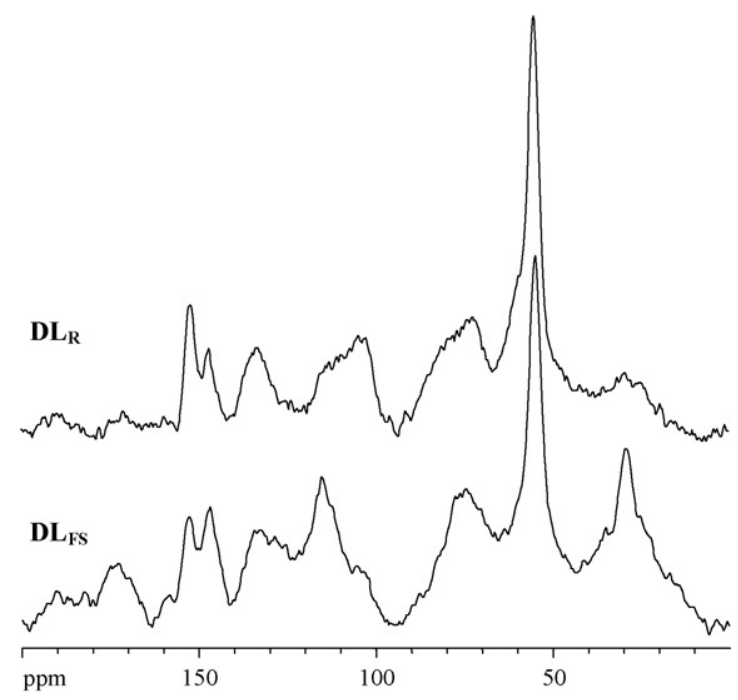

Fig. 2 - Solid ${ }^{13} \mathrm{C}$ CP/MAS NMR spectra of floral stalk (DLFS) and rachis $\left(D L_{R}\right)$ lignins.

Floral stalk and rachis constitute two different fractions of the banana plant stalk. Floral stalk develops through the rhizome, 10-15 months after the emergence of a new banana plant, in the centre of the pseudo-stem and emerges as a terminal inflorescence. In the external stalk, called rachis, are clustered the flowers and the banana fruits. Floral stalk is constituted by cellulose and, in large extent, by starch, which is crucial for the fruit development. In contrast, cellulose is the most abundant component in rachis, a fibrous material, which has the function of bear the bunch of bananas (Oliveira et al., 2007). Since these two stalk fractions have different physiological functions and general chemical compositions, it is not surprising that they possess lignins with rather different structures.

\subsection{Analysis of lignin structure by FTIR, ${ }^{13} \mathrm{C}$ CP-MAS NMR and UV spectroscopy}

The FTIR spectra of lignins from the two stalk fractions of banana plant showed notable differences (Fig. 1). Namely, floral stalk lignin contained higher amounts of aliphatic moieties of non-lignin origin than rachis lignin. These contaminations belong to fat substances as follows from the absorptions at 2918 and 2850, assigned to $\mathrm{C}-\mathrm{H}$ stretching in aliphatic moieties, and $1700-1710 \mathrm{~cm}^{-1}$, corresponding to $\mathrm{C}=0$ stretching of carboxylic acids. This proposition was corroborated with ${ }^{13} \mathrm{C}$ Cross Polarization-Magic Angle Spinning NMR spectra (Fig. 2), which revealed the characteristic resonances at $10-35 \mathrm{ppm}$, assigned to $-\mathrm{CH}-$ and $-\mathrm{CH}_{2}-$ moieties in aliphatic chains, and signals at $170-175 \mathrm{ppm}$, assigned to $\mathrm{C}=\mathrm{O}$ moieties in carboxyl and ester groups (Martínez et al., 1999; Hatfield et al., 1987). Similarly to leaf sheath lignin (Oliveira et al., 2006a), the purification of dioxane lignins from stalk fractions did not remove all aliphatic impurities, indicative that they are strongly bounded or even chemical linked to lignin.

The $A_{1462} / A_{1594}$ ratio in FTIR spectra, directly related to the amounts of methoxyl groups (Sarkanen et al., 1967), was smaller for $\mathrm{DL}_{\mathrm{FS}}$ than for $\mathrm{DL}_{\mathrm{R}}$, indicating that $\mathrm{DL}_{\mathrm{FS}}$ contains 


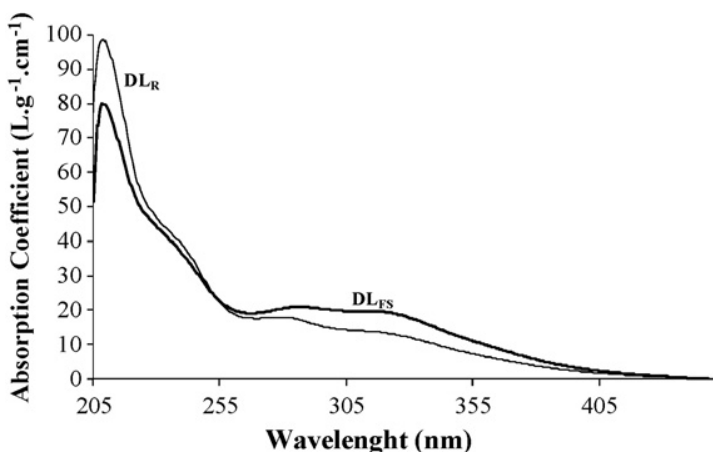

Fig. 3 - UV spectra of dioxane lignins isolated from floral stalk $\left(\mathrm{DL}_{\mathrm{FS}}\right)$ and rachis $\left(\mathrm{DL}_{\mathrm{R}}\right)$ of banana plant.

fewer amounts of $\mathrm{S}$ units than $\mathrm{DL}_{\mathrm{R}}$. In contrast, the specific absorptions at $835 \mathrm{~cm}^{-1}$ and at $1164 \mathrm{~cm}^{-1}$, assigned to $\mathrm{H}$ units (Faix, 1991), were more intensive in the FTIR spectrum of $\mathrm{DL}_{\mathrm{FS}}$ than in the spectrum of $\mathrm{DL}_{R}$. These structural differences between lignins were additionally confirmed by ${ }^{13} \mathrm{C}$ CP-MAS NMR spectroscopy (Fig. 2). Thus, the resonance at 152, assigned to C-3/C-5 in S units (Hawkes et al., 1993), was much stronger in the spectrum of $\mathrm{DL}_{\mathrm{R}}$ than in the spectrum of DLFS. Simultaneously, the resonance intensities at about 159-160 ppm, assigned to $\mathrm{C}-4$ in $\mathrm{H}$ units, were stronger in the spectrum of $\mathrm{DL}_{\mathrm{FS}}$ than in the spectrum of $\mathrm{DL}_{\mathrm{R}}$ (Fig. 2). The intensity of signals at 110-125 ppm, assigned to C-2,5,6 in G units, was significantly higher for $\mathrm{DL}_{\mathrm{FS}}$ than for $\mathrm{DL}_{\mathrm{R}}$, indicating that former lignin contains a higher proportion of $\mathrm{G}$ units.

The UV spectra of stalk lignins (Fig. 3) show the main absorption bands typical for the dioxane lignins from other annual plants (Seca et al., 2000, 1998). Extinction coefficients $(\varepsilon)$ at 209, 230, 280 and $310 \mathrm{~nm}$ are listed in Table 1. In the case of $\mathrm{DL}_{\mathrm{R}}$, the lignin characteristic absorption maximum, corresponding to the $\pi \rightarrow \pi^{*}$ electronic transition in the aromatic ring, occurs at $276 \mathrm{~nm}$, that is lower than for $\mathrm{DL}_{\mathrm{FS}}(280 \mathrm{~nm})$. This hypsochromic shift is another indication for the higher content of syringyl units in $\mathrm{DL}_{\mathrm{R}}$ than in $\mathrm{DL}_{\mathrm{FS}}$ (Morohoshi, 1991).

The absorption at around $310 \mathrm{~nm}$, indicative for the presence of hydroxycinnamic acid type structures (Sun et al., 2003), is observed in both lignins, being more intensive for the DLFs. These results are in agreement with the FTIR data, where the characteristic bands at 1708 and $1630 \mathrm{~cm}^{-1}$, assigned to $\mathrm{C}=\mathrm{O}$ stretching of carboxylic acids and to stretching of $\mathrm{C}=\mathrm{C}$ moieties conjugated with aromatic rings (Herbert, 1971), respectively, are especially intense in the spectrum of DLFS. Overall, these results indicate that both lignins are of HGS

Table 1 - Extinction coefficients of $D_{F S}$ and $D L_{R}$ at different wavelengths

\begin{tabular}{lcc} 
Wavelength $(\mathrm{nm})$ & $\mathrm{DL}_{\mathrm{FS}}$ & $\mathrm{DL}_{\mathrm{R}}$ \\
\hline 209 & 80 & 99 \\
230 & 44 & 47 \\
$276 / 280^{\mathrm{a}}$ & 17 & 18 \\
310 & 20 & 14 \\
\hline a $276 \mathrm{~nm}$ for $\mathrm{DL}_{\mathrm{R}}$ and $280 \mathrm{~nm}$ for $\mathrm{DL}_{\mathrm{FS}}$. & \\
\hline
\end{tabular}

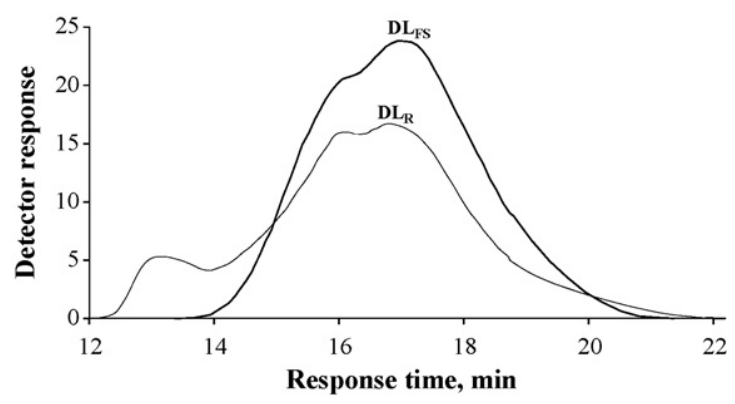

Fig. 4 - GPC molecular weight distribution of dioxane lignins obtained from banana plant floral stalk $\left(\mathrm{DL}_{\mathrm{FS}}\right)$ and rachis $\left(\mathrm{DL}_{\mathrm{R}}\right)$.

type, but $\mathrm{DL}_{\mathrm{R}}$ is richer in $\mathrm{S}$ units and poorer in $\mathrm{G}$ and $\mathrm{H}$ units when compared to DLFs.

According to Faix et al. (1994), the analysis of FTIR spectra allows the prediction of the lignin condensation degree. The ratio between the sum of the absorbance of seven minimum $\left(1550,1484,1440\right.$ 1395, 1300, 1177 and $\left.1070 \mathrm{~cm}^{-1}\right)$ and six maximum peaks $(1510,1463,1425,1329,1224$ and 1140 or $1125 \mathrm{~cm}^{-1}$ ) is proportional to the cross-linking index. The values found for $\mathrm{DL}_{\mathrm{FS}}$ and for $\mathrm{DL}_{\mathrm{R}}$ (0.64 and 0.55, respectively) suggest that floral stalk lignin is more condensed than rachis lignin (Faix et al., 1994).

\subsection{Molecular weight analysis}

The molecular weight distribution of $\mathrm{DL}_{\mathrm{FS}}$ and $\mathrm{DL}$, as revealed by GPC analysis, showed a bimodal mode (Fig. 4). The first maximum at about $16 \mathrm{~min}$ might correspond to the lignin fraction chemically linked to suberin-like compounds that affected the hydrodynamic volume of lignin macromolecules (Oliveira et al., 2006a). The second maximum at about $17 \mathrm{~min}$ is related to the lignin fraction free of suberin-like compounds. The small fraction of $\mathrm{DL}_{\mathrm{R}}$ eluted at about 13 min could be attributed to the macromolecules suffering a strong association due to the presence of specific bound non-ionizable aliphatic moieties. For example, rachis contained the highest proportion of long chain aliphatic alcohols ( $>20)$ among other morphological parts of banana plant (Oliveira et al., 2006b). Formally determined molecular weights $\left(M_{\mathrm{W}}\right)$ found for $\mathrm{DL}_{\mathrm{R}}$ and for $D L_{F S}$ were of 5400 and $3750 \mathrm{Da}$, respectively.

\subsection{Nitrobenzene oxidation}

The analysis of nitrobenzene oxidation products from two morphological parts of stalk (sawdust) confirmed the general conclusions on the proportion of structural units in lignins suggested based on FTIR and ${ }^{13} \mathrm{C}$ CP-MAS NMR. Only uncondensed lignin structural units are accessible to this analysis. The proportion of H:G:S units was 17:48:35 in floral stalk and 11:18:71 in rachis. Thus, the content of $\mathrm{H}$ structures in floral stalk lignin was roughly $50 \%$ higher, and the content of $\mathrm{S}$ units about half of that in rachis lignin. The pre-extraction of sawdust with alkaline solution before the dioxane lignin isolation led to insignificant changes in H:G:S ratio of the floral stalk (15:48:37) and significant loss of $\mathrm{H}$ units of the rachis 
<smiles>CCOc1ccc(C(C)=O)cc1</smiles>

1<smiles>CCOc1ccc(C(C)=O)cc1C</smiles>

2<smiles>COC(=O)c1cc(OC)c(OC)c(OC)c1</smiles>

3<smiles>CCOc1c(OC)cc(C(=O)OC)cc1C(=O)OC</smiles>

4<smiles>CCOc1cc(C(=O)OC)c(C(=O)OC)cc1OC</smiles>

5<smiles>CCOc1cc(C(C)=O)cc(Oc2ccc(C(=O)OC)cc2OC)c1OC</smiles>

8<smiles>CCOc1c(OC)cc(C(C)=O)c(C(=O)OC)c1OC</smiles>

6<smiles>CCOc1c(OC)cc(C(=O)OC)cc1-c1cc(C(=O)OC)cc(OC)c1OCC</smiles>

7<smiles>CCOc1cc(C(C)=O)cc(OC)c1Oc1c(OC)cc(C(C)=O)cc1OC</smiles>

9<smiles>CCOc1ccc(C(C)=O)cc1-c1cc(C(C)=O)cc(OC)c1OCC</smiles>

10

Fig. 5 - Carboxylic acid methyl esters structures obtained from permanganate oxidation analysis.

(5:20:75) lignin. This can be explained both by different stability of interunit bonds between $\mathrm{H}$ units and bulk lignin in these preparations or/and by different alkalinity depletion under the analysis conditions.

\subsection{Permanganate oxidation}

The proportion of different non-condensed/condensed structural units was evaluated by analysis of permanganate oxidation products. In spite of only phenolic lignin units are accessible for this analysis it is well accepted that these units reflect the structural features of a whole lignin sample. The molar proportions of oxidation products (Fig. 5) are summarized in Table 2 .

The relative abundance of products 1-3 after PO analysis of $\mathrm{DL}_{\mathrm{FS}}$ and $\mathrm{DL}_{\mathrm{R}}$ (Table 2) confirm the previous conclusions concerning the higher proportion of $S$ units (product 3 ) and lower proportion of $\mathrm{H}$ (product 1 ) and $\mathrm{G}$ (product 2) units in $\mathrm{DL}_{\mathrm{R}}$ when compared to $\mathrm{DL}_{\mathrm{FS}}$.

Among condensed structures those giving the products 4 ( $\beta-5^{\prime}$ structures), 5/6 (presumably of $\alpha-6^{\prime}$ type), 7/10 (biphenyl type, 5-5') and $8 / 9$ (diaryl ether type, 4-O-5') have been detected in PO analysis (Table 2). The detection of small amounts of

Table 2 - Molar proportions of permanganate oxidation products 1-10 from dioxane lignins

\begin{tabular}{lllllllllll} 
Samples & 1 & 2 & 3 & 4 & 5 & 6 & 7 & 8 & 9 & 10 \\
\hline Floral stalk & 33 & 34 & 11 & 8 & 2 & 1 & 8 & 1 & 2 & $\operatorname{tr}$ \\
Rachis & 23 & 28 & 31 & 4 & 2 & 2 & 3 & 1 & 6 & $\operatorname{tr}$ \\
\hline See Fig. 5 for structures assignments; tr: traces (<0.5 mol.\%). & \\
\hline
\end{tabular}

product 10 (Fig. 5) indicates some $p$-hydroxyphenyl units 5-5' linked with other structural units in lignin (Table 2). Based on the proportion of products 4-10, arisen in the oxidation of condensed phenylpropane structures (Table 2), it can be concluded that the floral stalk lignin is much more condensed than rachis lignin, which is in agreement with FTIR results. It may be also concluded that $\beta-5^{\prime}$ and $5-5^{\prime}$ biphenyl structures were the most abundant condensed structures in the floral stalk lignin, whereas the most abundant condensed structures in rachis lignin were the structures of 4-0-5'diaryl ether type. The structures of isotaxiresinol type $\left(\alpha-6^{\prime}\right)$, giving rise the products 5 and 6 , may be present in lignin or formed from $\beta-\beta^{\prime}$ structures under acidolytic isolation procedure (Evtuguin et al., 2001). Additionally, the provenance of products 5 and 6 may be assigned to phenylisochroman type structures ( $\beta$ $6^{\prime}$ ) found previously in wood lignins (Nimz, 1974; Sakakibara, 1991). The small amounts of products 5 and 6 (1-2 mol.\%) indicate the low abundance $\alpha-\sigma^{\prime} / \beta-\sigma^{\prime}$ type structures in stalk lignin (Table 2).

\subsection{Quantitative ${ }^{13} \mathrm{C}$ NMR analysis}

The structural features of floral stalk and rachis lignins were assessed in more details employing quantitative ${ }^{13} \mathrm{C} N \mathrm{NM}$ spectroscopy. The quantitative ${ }^{13} \mathrm{C}$ NMR spectra are presented in Fig. 6 . In contrast to the rachis lignin, the quantitative ${ }^{13} \mathrm{C}$ NMR spectrum of the floral stalk lignin could be obtained only as acetylated sample due to its incomplete dissolution in DMSO- $\mathrm{d}_{6}$ without derivatization. Although acetylated lignin preparations are often considered as not fully representative of the original lignin, because some of the material may be lost during derivatization, resulting in lignin fractionation, the isolated yield of acetylated $\mathrm{DL}_{\mathrm{FS}}$ was close to those reported as 


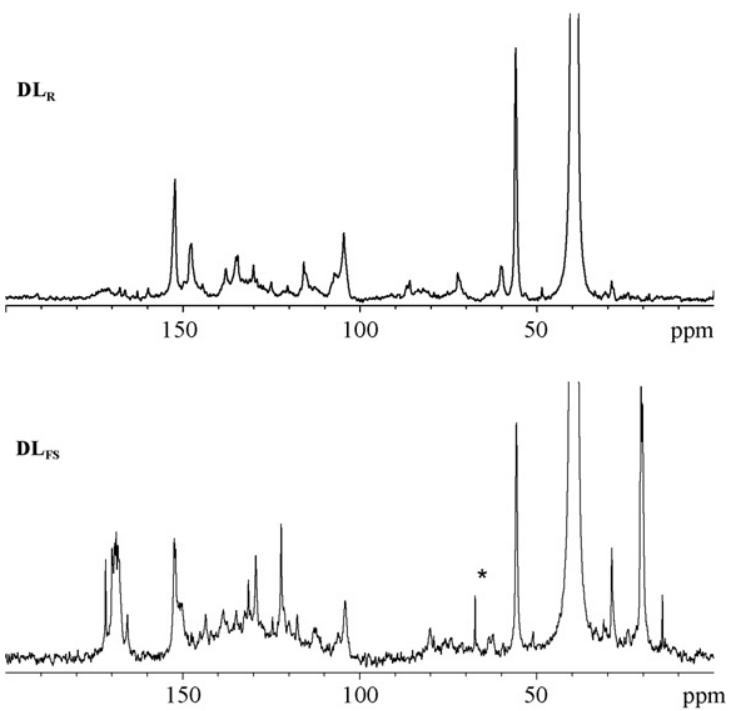

Fig. $6-{ }^{13} \mathrm{C}$ NMR spectra of acetylated floral stalk (DLFS) and non-acetylated rachis $\left(D_{R}\right)$ dioxane lignins isolated from banana plant (solvent contaminations are marked by asterisk).

theoretically predicted (about 130\%, w/w) (Capanema et al., 2004).

The carbon assignments in lignin structural elements were made based on previously reported results (Nimz et al., 1981; Ralph et al., 1996; Lapierre, 1993; Robert, 1992) and confirmed using proton-carbon correlation spectroscopy (HSQC). The highly sensitive HSQC technique provided the essential structural information on the presence/absence of specific lignin moieties in lignin preparations thus making analysis of the lignin structure with quantitative ${ }^{13} \mathrm{C}$ NMR easier and more accurate. The assignments for proton-carbon cross-peaks in the main structures are presented in Figs. 7 and 8.

After the characterization of floral stalk and rachis lignins by 2D NMR spectra (Figs. 7 and 8), the lignin structures were quantified using ${ }^{13} \mathrm{C}$ NMR. Although signals of some lignin moieties were overlapped in the ${ }^{13} \mathrm{C}$ NMR spectra, in most cases, it is possible to calculate the quantity of different structures by following the algorithms presented in Tables 3 and 4 . The $2 \mathrm{D}$ and ${ }^{13} \mathrm{C}$ spectra indicate the near absence of typical

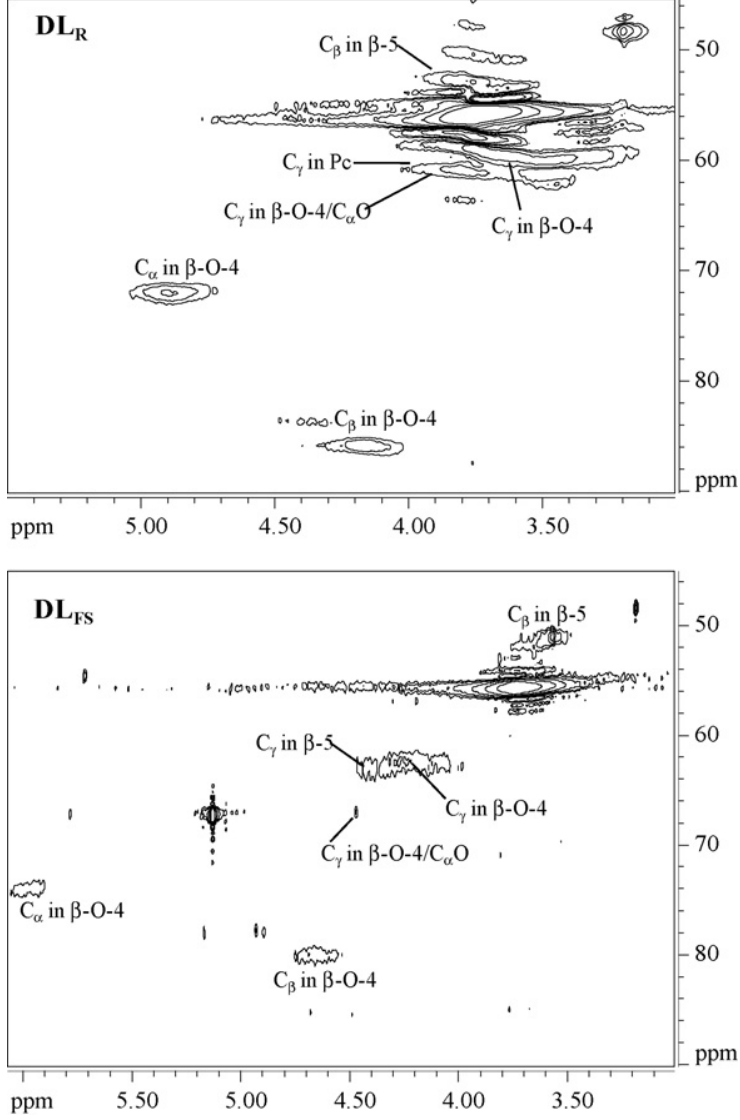

Fig. 7 - HSQC spectra showing aliphatic region of floral stalk acetylated lignin $\left(\mathrm{DL}_{\mathrm{FS}}\right)$ and non-acetylated rachis lignin $\left(D_{R}\right)$ isolated from banana plant.

carbohydrate signals, confirming the low content of associated polysaccharides in both lignins $(<1 \%)$

In the $\mathrm{DL}_{\mathrm{R}}$ spectra the integral at $103-164 \mathrm{ppm}\left(\mathrm{I}_{103-164}\right)$ was set as the reference, assuming that it includes six aromatic carbons, whereas in DLFS spectrum the region at 103-156 ppm (I103-156) was selected. All structural moieties were expressed per one aromatic ring $\left(\mathrm{C}_{6}\right)$ dividing the integrals corresponding to aromatic carbons per 6 (Tables 3 and 4). According to HSQC studies, the amount of olefinic carbon atoms from coniferyl alcohol, $p$-coumaric (Pc) and ferulic (Fe) acids structures in

Table 3 - Functional moieties per aromatic group in $\mathrm{DL}_{\mathrm{R}}$ as revealed by ${ }^{13} \mathrm{C}$ NMR spectroscopy

\begin{tabular}{|c|c|c|}
\hline Structure & Calculation & Value \\
\hline$\beta-\beta^{\prime}+\beta-5^{\prime}$ & $\left(I_{51.5-54.0} \times 6\right) /\left(I_{103-164}(\right.$ corrr $)$ & 0.02 \\
\hline $\mathrm{OCH}_{3}$ & $\left(I_{55.0-57.0} \times 6\right) /\left(I_{103-164}(\right.$ corr $\left.)\right)$ & 1.55 \\
\hline$\beta-O-4^{\prime}$ without $C_{\alpha}=0$ & $\left(I_{58.5-60.7} \times 6\right) /\left(I_{103-164}(\right.$ corr $)$ & 0.32 \\
\hline$\beta-O-4^{\prime}$ with $C_{\alpha}=0$ & $\left(I_{62.0-63.0} \times 6\right) /\left(I_{103-164}(\right.$ corr $\left.)\right)$ & 0.02 \\
\hline Coniferyl alcohol & $\left(I_{61.5-62.0} \times 6\right) /\left(I_{103-164}(\right.$ corr $\left.)\right)$ & 0.02 \\
\hline$p$-Coumaric acid (Pc) & $\left(I_{159.0-161.0} \times 6\right) /\left(I_{103-164(\text { corr })}\right)$ & 0.05 \\
\hline Ferulic acid (Fe) & {$\left[\left(I_{166.0-168.0}-I_{159.0-161.0}\right) \times 6\right] /\left(I_{103-164(\text { corr })}\right)$} & 0.05 \\
\hline Esterified Pc $+\mathrm{Fe}$ & {$\left[I_{167.8} \times 6\right] /\left(I_{103-164(\text { corr })}\right)$} & 0.04 \\
\hline Etherified Pc $+\mathrm{Fe}$ & {$\left[I_{166.3} \times 6\right] /\left(I_{103-164}\right.$ (corr) $)$} & 0.06 \\
\hline $\mathrm{H}$ & $\left(I_{159-164} \times 6\right) /\left(I_{103-164}\right.$ (corr) $)$ & 0.05 \\
\hline$S / G$ & $I_{103-110} \times 3 /\left(I_{110-124}-I_{166-168}-I_{61.5-62}\right) \times 2$ & 2.25 \\
\hline
\end{tabular}


Table 4 - Functional moieties per aromatic group in acetylated DLFS as revealed by ${ }^{13} \mathrm{C}$ NMR spectroscopy

\begin{tabular}{|c|c|c|}
\hline Structure & Calculation & Value \\
\hline$\beta-1+\beta-5^{\prime}$ & $\left(I_{50.0-52.5} \times 6\right) /\left(I_{103-156}\right.$ (corr) $)$ & 0.16 \\
\hline $\mathrm{OCH}_{3}$ & $\left(I_{54.8-57.0} \times 6\right) /\left(I_{103-156}(\right.$ corr $\left.)\right)$ & 0.87 \\
\hline$\beta-O-4$ without $C_{\alpha}=0$ & $\left(I_{61.0-63.0} \times 6\right) /\left(I_{103-156}\right.$ (corr) $)$ & 0.12 \\
\hline$p$-Coumaric + ferulic acids & $\left(I_{142.5-144.0} \times 6\right) /\left(I_{103-156}(\mathrm{corr})\right)$ & 0.19 \\
\hline $\mathrm{H}$ & 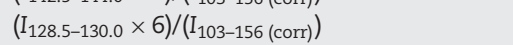 & 0.19 \\
\hline$S / G$ & $I_{103-110} \times 3 /\left(I_{110-125}-I_{117-118}-I_{128.5-130.0}\right) \times 2$ & 0.77 \\
\hline
\end{tabular}

both lignins is significant and the correction for their contribution to the integral at 102-156 and 102-164 ppm for DL $L_{F S}$ and $\mathrm{DL}_{\mathrm{R}}$, respectively, was necessary:

DLFS $\quad I_{103-156(\text { corrected) }}=I_{103-156}-I_{117-118}-I_{143-144}$

$\mathrm{DL}_{\mathrm{R}} \quad \mathrm{I}_{103-164 \text { (corrected) }}=\mathrm{I}_{103-164}-2 \mathrm{I}_{166-168}-2 \mathrm{I}_{61.5-62}$

The resonances at 118 and $143 \mathrm{ppm}$ in the DLF spectrum were assigned to $C_{\beta}$ and $C_{\alpha}$, respectively, in $p$-coumaric and ferulic acid structures. The resonances at 167.8 and $166.4 \mathrm{ppm}$ in the $\mathrm{DL}_{\mathrm{R}}$ spectrum were assigned to carbons in carboxyl and ester groups, respectively, in $p$-coumaric and ferulic acid structures (Lapierre, 1993; Ralph et al., 1996). A small resonance at $61.8 \mathrm{ppm}$ was assigned to $\mathrm{C}_{\gamma}$ in cinnamyl alcohol type structures (Nose et al., 1995).

The ${ }^{13} \mathrm{C}$ NMR spectra of floral stalk and rachis lignins exhibit signals in the aliphatic region (10-35 ppm) (Fig. 6), which were mainly found in $\mathrm{DL}_{\mathrm{FS}}$. The signals in this region

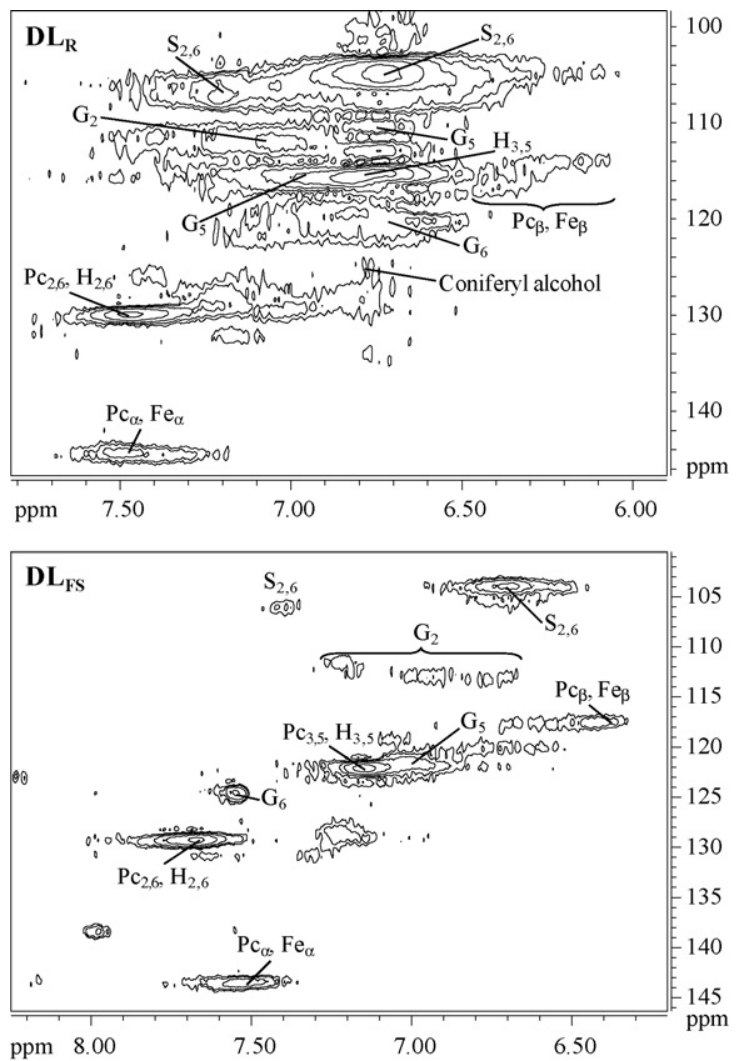

Fig. 8 - HSQC spectra showing the aromatic region of floral stalk acetylated lignin $\left(D_{\mathrm{FS}}\right)$ and non-acetylated rachis lignin $\left(D L_{R}\right)$ isolated from banana plant. are usually considered as impurities from extractives like fatty acids. It was evidenced previously that these aliphatic moieties belongs to suberin-like substance and are chemically linked to the lignin in the leaf sheaths of the banana plant (Oliveira et al., 2006a). The same feature may be suggested for the stalk lignin, because these aliphatic structures cannot be separated even after the exhaustive extraction of lignin with chloroform. The multimodal molecular distribution of floral stalk and rachis lignins is another proof for their structural association with suberin-like compounds.

According to assignments in HSQC spectrum (Fig. 7), the amount of $\beta-5^{\prime}$ structures per $C_{6}$ in the $D_{F S}$ spectrum $\left(0.16 / C_{6}\right)$ was calculated by integration of the $C_{\beta}$ resonance at $50.0-52.5 \mathrm{ppm}$ in these structures (Table 4). This is much higher than the content of $\beta-5^{\prime}$ structures in $\mathrm{DL}_{R}$ (Table 3 ). The small proportion of $\beta-1$ structures can also contribute in this region, however their amount is certainly less than $0.02 / C_{6}$. The higher abundance of $\beta-5^{\prime}$ structures in $D_{F S}$ than in $\mathrm{DL}_{\mathrm{F}}$ corroborates with the conclusions made based on the PO results (Table 2). The amounts of $\beta-\beta^{\prime}$ structures in DLFs was difficult to estimate, based on integral of $C_{\beta}(3.15 / 54.4 \mathrm{ppm})$, because of strong overlapping of this signal with carbon resonance in methoxyl groups. No $\beta-\beta^{\prime}$ structures in $D_{R}$ were detected in the HSQC spectrum (Fig. 7). Probably, these structures were degraded during the isolation procedure, giving raise the cyclic $\left(\alpha-5^{\prime}+\beta-\beta^{\prime}\right)$ structures or are present in small amounts in lignin.

The amount of $\beta-O-4^{\prime}$ linked units in the spectrum of $\mathrm{DL}_{\mathrm{FS}}$ was estimated based on the resonance at $61.0-63.0 \mathrm{ppm}$ (Fig. 7), assigned to $C_{\gamma}$ in $\beta-O-4^{\prime}$ structures without $\alpha-C O$ (Ralph et al., 1996). Unfortunately the resonance of $C_{\gamma}$ in $\beta-O-4^{\prime}$ structures with $\alpha$-CO was overlapped with resonance of dioxane, which hindered their quantification (Fig. 7). The integration of resonances at 58.5-60.7 and 62.0-63.0 ppm assigned to $C_{\gamma}$ in $\beta$ $0-4^{\prime}$ structures without and with $\alpha-\mathrm{CO}$, respectively, allowed the estimation of these structures in $\mathrm{DL}_{R}$. The abundance of $\beta-O-4^{\prime}$ structures in $D_{F S}$ was much lower $\left(0.12 / C_{6}\right)$ when compared to amounts of these structures in $D L_{R}\left(0.32 / C_{6}\right)$ (Tables 3 and 4).

The characteristic tertiary carbon resonances from $\mathrm{S}$ units at $103-110 \mathrm{ppm}(\mathrm{C}-2,6), \mathrm{G}$ units at $110-125 \mathrm{ppm}(\mathrm{C}-2,5,6)$ and $\mathrm{H}$ units (including Pc) at 129-131 ppm (C-2,6) (Fig. 8) were used to assess the $\mathrm{H}: \mathrm{G}: \mathrm{S}$ ratios of $\mathrm{DL}_{\mathrm{FS}}$. According with the HSQC spectrum of $\mathrm{DL}_{\mathrm{FS}}$, it was necessary to correct the integral at 110-125 ppm for the C-3,5 from $\mathrm{H}$ and Pc/Fe units contribution at about $129 \mathrm{ppm}$ and $\mathrm{C}_{\beta}$ in Pc and Fe units at $118 \mathrm{ppm}$, as following: $I_{110-125}$ (corrected) $=I_{110-125}-I_{117-118}-I_{128.5-130.0}$ (Table 4). The integral of peak at $129 \mathrm{ppm}$ (C-2,6 in $\mathrm{H}$ units) is equivalent to the signal at $123 \mathrm{ppm}$ (C-3,5 in $\mathrm{H}$ units), which was over- 
lapped, however, with signals of C-5,6 in G units. The obtained H:G:S proportion in DLFS (19:45:36) was not very different from that obtained for in situ lignin by NO analysis (15:48:37). This is not surprising, because using both techniques the uncondensed lignin structural units were assessed.

In $\mathrm{DL}_{R}$, the amount of $\mathrm{H}$ type structures, other than Pc, were insignificant, as revealed from integrals of the signals at $156-158 \mathrm{ppm}$ (C-4 in corresponding structures) and were not considered in calculations. Comparing the intensities of the signals at $152.1 \mathrm{ppm}$ (C-3,5 in etherified $\beta-0-4^{\prime}$ linked $\mathrm{S}$ units) and 149.0-149.5 ppm (C-3 in etherified $\beta-0-4^{\prime}$ linked G units), which ratio is about 7:1 (Fig. 6), it is possible to conclude that $\mathrm{S}$ units in $\mathrm{DL}_{\mathrm{R}}$ are mainly ether-linked contributing to linear molecular fragments, whereas $G$ units are mainly non-etherified and frequently linked by carbon-carbon bonds representing terminal phenolic lignin units. This explains the higher abundance of $\mathrm{G}$ than of S units in PO analysis (Table 2) and the underestimation of the proportion of $S$ structural units in $\mathrm{DL}_{\mathrm{R}}(\mathrm{H}: \mathrm{G}: \mathrm{S}=5: 29: 66$, Table 3) when compared to that of in situ lignin of rachis (H:G:S=5:20:75) as determined by NO analysis. The presence of hydroxycinnamic acids was confirmed in both lignin spectra. Pc structures in $\mathrm{DL}_{\mathrm{R}}$ are mainly terminal phenolic units, because the signal at $159.8 \mathrm{ppm}$ (C-4 in phenolic Pc) is prevalent over the signal at $160.8 \mathrm{ppm}$ (C-4 in non-phenolic Pc). Thus, a significant part of the Pc amount $\left(0.05 / C_{6}\right)$ should be ester-linked to other lignin substructures, because the total amount of hydroxycinnamic structures with free carboxyl groups (means non-phenolic ones) is $0.04 / \mathrm{C}_{6}$ (resonance at $168.8 \mathrm{ppm}$ ) and the total amount of esterified and etherified Pc and Fe structures is $0.10 / C_{6}$ (Table 3). Almost all Fe units $\left(0.05 / \mathrm{C}_{6}\right)$ should be ether-linked.

In acetylated lignin spectrum, the presence of Pc and Fe units are evidenced by the signals at about 119 and $143 \mathrm{ppm}$, assigned to $C_{\beta}$ and $C_{\alpha}$ in these structures, respectively. Pc and Fe structures represent about $0.19 / C_{6}$, which was calculated from the integral of resonances at $142.5-144.0 \mathrm{ppm}$. The resonance of $\mathrm{C}-4$ in etherified Pc and $\mathrm{H}$ units usually appears at 160-162 ppm (Ralph et al., 1996; Capanema et al., 2004) and was absent in the DLFs spectrum (Fig. 6) indicating that almost all of Pc units should be in the form of ester. Unfortunately, it was impossible to quantify the esterified and non-esterified Pc structures in the $\mathrm{DL}_{\mathrm{FS}}$ spectrum, which signals normally found at about 168.8 and 167.5 ppm (Ralph et al., 1996), because these were overlapped by resonances of $\mathrm{CO}$ in acetates of primary (169.6-172 ppm), secondary (169.6-16 8.6 ppm) alcohols and phenols (168.6-166 ppm).

More likely, Pc and Fe structures are ester-linked to $\mathrm{C}_{\alpha}$ and $\mathrm{C}_{\gamma}$ atoms in lignin substructures. The corresponding proton/carbon correlations were found in HSQC spectra: 4.28/ 63.4 ppm in $\mathrm{DL}_{\mathrm{R}}$ and $4.32 / 63.5 \mathrm{ppm}$ in $\mathrm{DL}_{\mathrm{FS}}\left(\mathrm{C}_{\gamma}\right.$ in $\gamma$-esterified $\beta-O-4^{\prime}$ structures); $5.95 / 73.4 \mathrm{ppm}$ in $\mathrm{DL}_{\mathrm{R}}$ and 6.03/75.8 ppm in $\mathrm{DL}_{\mathrm{FS}}$ ( $\mathrm{C}_{\alpha}$ in benzyl ester of $\beta-0-4^{\prime}$ structures) (Ralph et al., 1999). However, the suberin-like compounds also can be linked to lignin by ester linkages via ferulates (Bernards, 2002). The presence of resonances at 29.0 and 31.2 ppm (Fig. 6) confirm that a small part of them still remained in the purified lignin sample after the purification and chloroform extraction. A group of non-resolved signals at $171-173 \mathrm{ppm}$ in the ${ }^{13} \mathrm{C}$ NMR spectrum (Fig. 6) also evidenced the presence of ester-linked fatty/hydroxy acids.

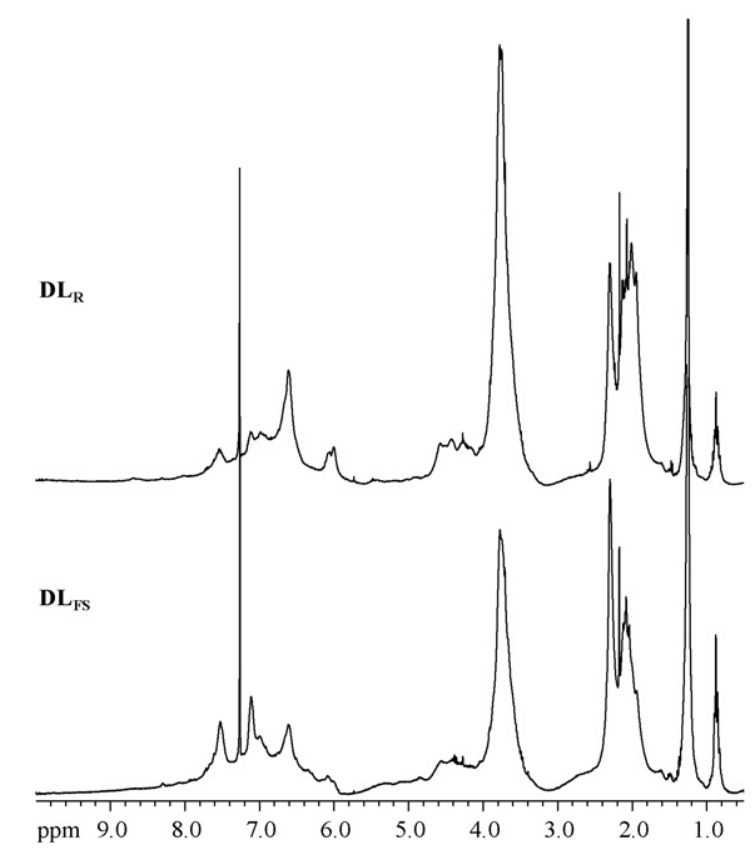

Fig. 9 - ${ }^{1} \mathrm{H}$ NMR spectrum of acetylated dioxane lignins obtained from floral stalk $\left(\mathrm{DL}_{\mathrm{SF}}\right)$ and rachis $\left(\mathrm{DL}_{\mathrm{R}}\right)$.

\section{6. ${ }^{1} \mathrm{H}$ NMR analysis}

Proton NMR spectroscopy was used to confirm the quantitative estimations of some structural elements done by ${ }^{13} \mathrm{C}$ NMR and to obtain additional structural information on lignin. All calculations were made per $\mathrm{C}_{9}$ unit using the resonance of methoxyl protons at 3.6-4.0 ppm as an internal standard. The ${ }^{1} \mathrm{H}$ NMR spectra of acetylated $\mathrm{DL}_{\mathrm{R}}$ and $\mathrm{DL}_{\mathrm{FS}}$ are presented in Fig. 9.

The abundance of $\beta-0-4$ structures was estimated based on the resonance of $\mathrm{H}_{\alpha}$ at 5.8-6.2 ppm (Chen and Robert, 1988). Thus, the value obtained for the content of $\beta-0-4$ structures without $\mathrm{C}_{\alpha}=\mathrm{O}\left(0.11 / \mathrm{C}_{9}\right.$ for $\mathrm{DL}_{\mathrm{FS}}$ and $0.32 / \mathrm{C}_{9}$ for $\left.\mathrm{DL}_{\mathrm{R}}\right)$ is similar to that determined by ${ }^{13} \mathrm{C}$ NMR spectroscopy per $\mathrm{C}_{6}\left(0.12 / \mathrm{C}_{6}\right.$ for $D_{F S}$ and $0.32 / C_{6}$ for $\left.D L_{R}\right)$. No characteristic signal at about 3.1-3.2 ppm, assigned to $\mathrm{H}_{\beta}$ in $\beta-\beta^{\prime}$ structures was found in the spectra of both lignins. This observation supports an idea that the abundance of these structures in stalk should be very low. The signals between 0.8 and $1.6 \mathrm{ppm}$, assigned to $\mathrm{CH}_{3}$ and $\mathrm{CH}_{2}$ in saturated aliphatic chains, respectively, suggest once more the presence of aliphatic compounds linked to lignin and confirm a higher amount of these compounds in the $\mathrm{DL}_{\mathrm{FS}}\left(3.88 / \mathrm{C}_{9}\right)$ than in $\mathrm{DL}_{\mathrm{R}}\left(1.69 / \mathrm{C}_{9}\right)$. The existence of suberin-like aliphatic chains covalently bound to the lignin polymer with similar resonances as above was already reported for monocotyledonous plants (Lundquist, 1992). The presence of proton signals from suberin-like aliphatic structures (including hydroxyacids) at 1.5-2.2 ppm did not allow the correct quantification of aromatic and aliphatic hydroxyl groups which acetate derivatives showed the resonances at the same region (Lundquist, 1992). The broad signal at around 7.4-7.6 ppm was assigned to $\mathrm{H}$ 2/H- 6 aromatic protons and $\mathrm{H}_{\alpha}$ in Pc structures (Ralph et al., 1996) confirming their significant amounts in both lignins, especially in the DLFS lignin. 


\section{Conclusions}

The results of the present study clearly show strong structural differences between floral stalk and rachis lignins, suggesting a different biosynthetic route for lignins in these two fractions of banana plant stalk. The divergences found have a scientific interest from point view of banana plant chemistry/physiology, and also of practical interest when dealing with the chemical processing of banana plant biomass. The structural differences are important enough to foresee eventual different reactivity for the floral stalk and rachis lignins during the pulping processes. For example, in contrast to rachis, the low S:G ratio, the low $\beta-0-4$ structures content and the high degree of lignin condensation should contribute to the lower reactivity of floral stalk lignin during pulping and bleaching processes. This disagreement in structural features of floral stalk and rachis lignins should be taken into account in the planning of new strategies for the rational utilization of banana plant biomass, particularly for the pulp and paper needs. Evidently, the floral stalk should be separated from stem and pseudo-stem materials for the better pulping performance of these banana plant fractions.

\section{Acknowledgments}

Portuguese Foundation for the Science and Technology (FCT) has sponsored this work. Lúcia Oliveira also thanks FCT for the awarding of a Ph.D. grant (BD/4749/2001). The authors also wish to thank the Cooperativa Agrícola dos Produtores de Frutas da Madeira, CRL for kindly providing the samples.

\section{REFERENCES}

Bernards, M.A., 2002. Demystifying suberin. Can. J. Bot. 80, 227-240.

Blakeney, A.B., Harris, P.J., Henry, R.J., Stone, B.A., 1983. A simple and rapid preparation of alditol acetates for monosaccharide analysis. Carbohydr. Res. 113, 291-299.

Capanema, E.A., Balakshin, M.Y., Kadla, J.F., 2004. A comprehensive approach for quantitative lignin characterization by NMR spectroscopy. J. Agric. Food Chem. 52, 1850-1860.

Chen, C.-L., 1992. Nitrobenzene and cupric oxide oxidations. In: Lin, S.Y., Dence, C.W. (Eds.), Methods in Lignin Chemistry. Springer-Verlag, Berlin, pp. 301-319.

Chen, C.-L., Robert, D., 1988. Characterization of lignin by $1 \mathrm{H}$ and 13C NMR spectroscopy. In: Wood, W.A., Kellogg, S.T. (Eds.), Methods in Enzymology, vol. 161. Academic Press, New York, pp. 137-158.

Cordeiro, N., Belgacem, M.N., Torres, I.C., Moura, J.V.C.P., 2004. Chemical composition and pulping of banana pseudo-stems. Ind. Crops Prod. 19, 147-154.

Cordeiro, N., Belgacem, M.N., Chaussy, D., Moura, J.C.V.P., 2005. Pulp and paper from 'Dwarf Cavendish' pseudo-stems. Cell. Chem. Technol. 39, 517-529.

Donaldson, L., Hague, J., Snell, R., 2001. Lignin distribution in coppice poplar, linseed and wheat straw. Holzforschung 55 (4), 379-385.

Evtuguin, D.V., Pascoal Neto, C., Silva, A.M.S., Domingues, P.M., Amado, F.M.L., Robert, D., Faix, O., 2001. Comprehensive study on the chemical structure of dioxane lignin from plantation
Eucalyptus globulus wood. J. Agric. Food Chem. 49, 4252-4261.

Faix, O., 1991. Classification of lignins from different botanical origins by FT-IR spectroscopy. Holzforschung 45 (Suppl.), 21-27.

Faix, O., Stevanovic-Janezic, T., Lundquist, K., 1994. The lignin of diffuse porous angiosperm tree Triplochyton scleroxylon $\mathrm{K}$. Schum with low syringylpropane content. J. Wood Chem. Technol. 14, 263-278.

FAO, 2006. FAO Statistical Databases. Available at URL. http://faostat.fao.org/site/567/DesktopDefault.aspx?PageID=567 (accessed 24th April 2006).

Faria, H., Cordeiro, N., Belgacem, M.N., Dufresne, A., 2006. Dwarf Cavendish as a source of natural fibers in polypropylene-based composites. Macromol. Mater. Eng. 291, 16-26.

Gellerstedt, G., 1992. Chemical degradation methods: permanganate oxidation. In: Lin, S.Y., Dence, C.W. (Eds.), Methods in Lignin Chemistry. Springer-Verlag, Berlin, pp. 322-333.

Hatfield, G.R., Maciel, G.E., Erbatur, O., Erbatur, G., 1987. Qualitative and quantitative analysis of solid lignin samples by carbon-13-nuclear magnetic resonance spectrometry. Anal. Chem. 59, 172-179.

Hawkes, G.E., Smith, C.Z., Utley, J.H.P., Vargas, R.R., Viertler, H., 1993. A comparison of solution and solid-state ${ }^{13} \mathrm{C}$ NMR spectra of lignins and lignin model compounds. Holzforschung 47, 302-312.

Herbert, H.L., 1971. Infrared spectra. In: Sarkanen, K.V., Ludwig, C.H. (Eds.), Lignins. Occurrence, Formation, Structure and Reactions. Wiley-Interscience, New York, pp. 267-297.

Lapierre, C., 1993. Application of new methods for the investigation of lignin structure. In: Jung, G.H., Buxton, D.R., Hatfield, R.D., Ralph, J. (Eds.), Forage Cell Wall Structure and Digestibility. ASA-CSSA-SSSA, Madison, WI, pp. 133-166.

Lundquist, K., 1992. Proton (1H) NMR spectroscopy. In: Lin, S.Y., Dence, C.W. (Eds.), Methods in Lignin Chemistry. Springer-Verlag, Berlin, pp. 242-249.

Martínez, A.T., Almendros, G., Conzález-Vila, F.J., Fründ, R., 1999. Solid-state spectroscopic analysis of lignins from several Austral hardwoods. Solid State NMR 15, 41-48.

Morohoshi, N., 1991. Chemical characterization of wood and its components. In: Hon, D.N.-S., Shiraishi, N. (Eds.), Wood and Cellulosic Chemistry. Marcel Dekker Inc., New York, pp. 331-394.

Nimz, H.H., 1974. Beech lignins proposal of a constitutional scheme. Angew. Chem., Int. Ed. Engl. 13, 313-321.

Nimz, H.H., Robert, D., Faix, O., Nemr, M., $1981 .{ }^{13} \mathrm{C}$ NMR spectra of lignins. 8. Structural differences between lignins of hardwoods, softwoods, grasses and compression wood. Holzforschung 35 (1), 16-26.

Nose, M., Bernards, M.A., Furlan, M., Zajicek, J., Eberhardt, T.L., Lewis, N.G., 1995. Towards the specification of consecutive steps in macromolecular lignin assembly. Phytochemistry 39, 71-79.

Oliveira, L., Freire, C.S.F., Silvestre, A.J.D., Cordeiro, N., Torres, I.C., Evtuguin, D., 2005. Steryl glucosides from banana plant Musa acuminata Colla var. Cavendish. Ind. Crops Prod. 22, 187-192.

Oliveira, L., Evtuguin, D., Cordeiro, N., Silvestre, A.J.D., Silva, A.M.S., Torres, I., 2006a. Structural characterization of lignin from leaf sheaths of banana plant "Dwarf Cavendish". J. Agric. Food Chem. 54, 2598-2605.

Oliveira, L., Freire, C.S.F., Silvestre, A.J.D., Cordeiro, N., Torres, I.C., Evtuguin, D., 2006b. Lipophilic extractives from different morphological parts of banana plant "Dwarf Cavendish". Ind. Crops Prod. 23, 201-211.

Oliveira, L., Cordeiro, N., Evtuguin, D.V., Torres, I.C., Silvestre, A.J.D., 2007. Chemical composition of different morphological parts from 'Dwarf Cavendish' banana plant and their potential as a non-wood renewable source of natural product. Ind. Crops Prod. 26, 163-172. 
Ralph, S.A., Ralph, J., Landucci, L.L., 1996. NMR database of lignin and cell wall model compounds. Available at URL http://ars.usda.gov/Services/docs.htm?docid=10491 (accessed November 2004).

Ralph, J., Marita, J.M., Ralph, S., Hatfield, R.D., Lu, F., Ede, R.M., Peng, J., Quideau, S., Helm, R.F., Grabber, J.H., Kim, H., Jimenez-Monteon, G., Zhang, Y., Jung, H.-J.G., Landucci, L.L., MacKay, J.J., Sederoff, R.R., Chapple, C., Boudet, A., 1999. In: Argyropoulos, D.S. (Ed.), Advances in Lignocellulosics Characterization. Tappi Press, Atlanta, p. 55.

Reddy, N., Yang, Y., 2005. Biofibers from agricultural byproducts for industrial applications. Trends Biotechnol. 23 (1), 22-27.

Robert, D., 1992. Carbon-13 nuclear magnetic resonance. In: Lin, S.Y., Dence, C.W. (Eds.), Methods in Lignin Chemistry. Springer-Verlag, Berlin, pp. 250-273.

Sakakibara, A., 1991. Chemistry of lignin. In: Hon, D.N.-S., Shiraishi, N. (Eds.), Wood and Cellulosic Chemistry. Marcel Dekker, New York, pp. 113-175.
Sarkanen, K.V., Chang, H.-M., Allan, G.G., 1967. Species variation in lignins. 2. Conifer lignins. Tappi J. 50, 583-586.

Seca, A.M.L., Cavaleiro, J.A.S., Domingues, F.M.J., Silvestre, A.J.D., Evtuguin, D., Pascoal Neto, C., 1998. Structural characterization of the bark and core lignins from kenaf (Hibiscus cannabinus). J. Agric. Food Chem. 46, 3100-3108.

Seca, A.M.L., Cavaleiro, J.A.S., Domingues, F.M.J., Silvestre, A.J.D., Evtuguin, D., Pascoal Neto, C., 2000. Structural characterization of the lignin from the nodes and internodes of Arundo donax Reed. J. Agric. Food Chem. 48, 817-824.

Sun, J.-X., Sun, X.-F., Sun, R.-C., Fowler, P., Baird, M.S., 2003. Inhomogeneities in the chemical structure of sugarcane bagasse lignin. J. Agric. Food Chem. 51, 6719-6725.

Terashima, N., Fukushima, K., 1993. Comprehensive model of the lignified plant cell wall. In: Jung, H.G., Buxton, D.R., Hatfield, R.D., Ralph, J. (Eds.), Forage Cell Wall Structure and Digestibilty. ASA-CSSA-SSSA, Madison, USA, pp. 247-270.

Zakis, G.F., 1994. Functional Analysis of Lignins and their Derivatives. Tappi Press, Atlanta, GA, pp. 31-33. 